\title{
Digital Labour in the University: Understanding the Trans- formations of Academic Work in the UK
}

\author{
Jamie Woodcock
}

London School of Economics and Political Science, London, UK, j.woodcock@lse.ac.uk, www.jamiewoodcock.net

\begin{abstract}
Universities have been the site of a variety of shifts and transformations in the previous few decades. Both the composition of students and academics are changing (to a lesser or greater extent), along with the ways in which teaching and research is supported, conducted, and delivered. The effects of neoliberalism, privatisation, precarious employment, debt, and digitalisation have been highlighted as important factors in understanding these changes. However, the ways in which these tendencies are expressed in universities - both in specific and general ways - remain fragmented and under-analysed. In particular, the role of academic labour processes, increasingly mediated through digital technology, remains in the background. There is a risk of viewing these transformations as abstracted, far removed from the day-to-day activities of academic labour on which universities rely. This article will therefore focus on connecting the broader changes in funding, organisation, and digital technology to the labour processes of academics. Rather than seeking a return to a romanticised pre-neoliberal university, this article explores the possibilities of resistance and alternatives to the university as it is now.
\end{abstract}

Keywords: Digital Labour, Academia, Autonomism, Work, Labour Process

\section{Introduction}

The university has been the site of a variety of shifts and transformations in the previous few decades. Both the composition of students and academics are changing (to a lesser or greater extent), along with the ways in which teaching and research is supported, conducted, and delivered. There are two key dynamics that will be examined in this paper: the neoliberalisation of the university with new management techniques and strategies, and the introduction of new digital technologies. These two dynamics are closely bound up with each other and are transforming not only the university, but also the forms of academic work.

The university has been a space from which much research on digital labour has originated, yet as a research site it remains comparatively understudied in this context. The focus of much research has been on the neoliberalisation of the university, in the sense of the political economy of higher education, with less on the effects of technology that are also bound up with these processes. As Morgan and Baert (2015) note, too often universities are considered through 'tired clichés' as "ivory towers"' and "dreaming spires"', leading to an 'unhelpful black-boxing of these zones of social life from attentive sociological enquiry, usually on the odd assumption that the "real world" is somehow always going on elsewhere.' For example, labour process theory originated in universities, seeking to uncover what Marx $(1990 / 1867,280)$ called the 'hidden abode' of exploitation at work, yet the site from which the research takes place remains obscured to this analytical lens.

There is a deep irony in the lack of application of the conceptual tools of labour process analysis and other ways of studying work to the academic environment itself. 
Furthermore, this irony continues with the overwork of academics who write not only about work, but increasingly about anti-work politics. The patterns of work may be accelerating, but the way in which the work is carried out is also transforming through the application of digital technologies.

The aim of this article, therefore, is to analyse academic work and its transformation within the university. This begins with discussion on how technology is transforming work, the role of knowledge, and universities under capitalism. The next part situates academic work, particularly in the UK, within the broader dynamics of neoliberalism. After discussing this context, the article moves on to specifically discussing the contemporary academic labour process. The final section analyses these changes through the lens of class composition, suggesting future directions for research.

\section{Knowledge at Work}

For Marx (1991/1894, 1017), the labour process was an important starting point for analysis, because 'its simple elements remain common to all social forms of development.' Thus, even when examining the complex digital technologies found today, the labour process remains a key way to understand how capitalism has developed in various ways. When addressing questions of work in the university, the analysis is concerned with processes of knowledge construction. However, with Marx, there was 'no detailed discussion of the institution of the university, higher education, or academic research', and only a 'mention of scientists employed by capitalists in privately organized institutions' (Szadkowski 2016b, 12). Despite the application of terms 'knowledge work' or 'knowledge economy' (Nonaka 1998), it is important not to exceptionalise academic labour as though knowledge and information is not used in other forms of work. For example, the role of information in the factory was identified as key by Romano Alquati (1975,113; quoted in Wright 2016, 4), who argued that:

Information is the most important thing [l'essenziale] about labour-power: it is what the worker, by means of constant capital, transmits to the means of production upon the basis of evaluations, measures, elaborations, in order to work [operare] upon the object of labour all those changes in form that give it the use value required. The 'disposability' of the worker leads him to be a qualitative indice of socially necessary labour time, by which the 'product' is valued as the 'recipient' of a certain quantity of 'information'.

This takes a very different approach to many of the studies of the labour process in the factory, often focusing on the physical labour process and methods of discipline and control. Similarly, the importance of information has been argued for by Castells $(2000$, 17 ), stating that 'knowledge and information are critical elements in all modes of development, since the process of production is always based on some level of knowledge in the processing of information.' However, as Pasquinelli $(2011,4)$ has noted, what Alquati introduces is the "concept of valorising information [...] as the "flow" running along and feeding those circuits' in the factory.

The importance of information in the production process was also noted by Frederick Taylor, albeit from the perspective of capital. As part of the preparation of scientific management, Taylor $(1967,36)$ argued for the 'gathering together all of the traditional knowledge which in the past has been possessed by the workmen.' This process of knowledge theft from workers by managers was carried out in practice by Taylor during 
his experiments at the Midvale Steel Company, in which he worked on machine lathes trying to understand the labour process from the shop floor. Clearly, the importance of information therefore pre-dates the rise of contemporary digital technology. For Alquati, the importance of information was twofold. First as 'control information', analogous to the knowledge theft of Taylorism outlined above. The second is information 'that constitutes the collective legacy of the working class [...] productive information tout court' (Alquati 1975, 114; quoted in Wright 2016,5), that which capital attempts to subsume and transform into the former. Alquati's prescient analysis focuses on the way in which this valorised information 'enters the cybernetic machine and it is transformed into a sort of machinic knowledge' (Pasquinelli 2011, 5). This involves the ability to 'encode workers' knowledge into bits and consequently transform bits into numbers for economic planning', or as Pasquinelli $(2011,5)$ puts it: 'cybernetic code transforms information into value.'

The development of digital technology has been driven by a combination of the military, research intensive universities, and the defence industries, while being 'mediated, ironically, by hacking and homebrew computing cultures that believed "information wants to be free"' and 'Silicon Valley culture' (Dyer-Witheford 2010, 488). This belief in the freedom of information ties into Marx's (1976/1857, 690-712) discussion of the 'general intellect' found in the 'fragment on the machines.' Virno (2001) argues that the idea of the 'general intellect' entails the claim that 'due to its autonomy from it, abstract knowledge [...] is in the process of becoming no less than the main force of production and will soon relegate the repetitious labour of the assembly line to the fringes.' This is a potential of automation: to increase the autonomy of workers, freeing them from the kinds of work that have previously been dominant. However, as Virno (2001) continues, the realisation of this tendency arrives with 'no revolutionary or even conflictual implication.' Tronti (1965) argued that the 'political history of capital' can be read as a 'history of the successive attempts of the capitalist class to emancipate itself from the working class.' This is expressed in the long-term tendency towards the increase in the ratio between constant capital (raw material and machines) and variable capital (or living labour), discussed by Marx $(1977,762)$ as the organic composition of capital. Although in the contemporary context, Dyer-Witheford $(2010,494)$ suggests it would perhaps be better to term this the 'inorganic composition of capital', given the rise of automated and automating machines. This is especially pertinent when considering the claim that robots or algorithms are coming to replace workers, for example found in the recent claim that $47 \%$ of jobs are at risk of being automated (Frey and Osborne 2013).

The contemporary transformation of work has involved the introduction of new types of technology and management practices. In this context, the application of technology involves the augmentation of the labour process in various ways, and can clearly be seen with office work. As Huws $(2001,7)$ has noted, office work (despite the challenges of clearly delineated it) has been subjected to a range of transformations, from the 'impact of the restructuring of markets', 'the ideological triumph of neoliberalism', to the 'impact of technological change.' For Handy (1984), the application of digital technology was claimed to be the start of a positive transformation of work. However, the reality has become closer to that identified by Braverman (1999): the degradation and deskilling of work under managerial control. New technologies have reduced paperwork and increased the pace of tasks, in effect augmenting the labour process by automating parts of it, and there have been increasing applications of technology for supervision and control. For example, Bain et al. $(2002,3)$ previously noted that it is now "feasible to attain total knowledge, in "real time", of how every employee's time was 
being deployed, through the application of electronic monitoring equipment.' In the example of call centres, the possibilities of these new surveillance technologies have been captured by Fernie and Metcalf $(1997,3)$ as being like an 'electronic panopticon.'

The role of knowledge and information - and attempts at control and surveillance are clearly important in the context of a university. These institutions of higher education have historically served two functions: the construction of knowledge through research and the provision of teaching and training. Broadly speaking, universities began as elite institutions, training the next generation of the ruling class and providing ideological resources. From the 1960s onwards, universities in the UK shifted to the provision of mass education, with greatly increasing numbers of students. Universities have therefore been considered public institutions, separate from the market, and in the UK, formally separate from the state itself. However, the widespread changes that are captured with the often-clumsy designation of neoliberalism, has involved widespread changes to the university. Roggero $(2011,3)$ identified three key trends: the first is a blurring or collapsing of the public/private distinction in universities, with the integration of market forces and private interests. The second is the failure of the university as 'an elevator for social mobility', with a university degree no longer able to offer better employment prospects, becoming 'necessary to access even a precarious job.' With this change students are much less likely to conform to stereotypes of being lazy and living off government grants, with many no longer 'the classic figure of worker-in-training' but a precarious worker already. Thirdly, there is a crisis in the production of knowledge itself in the university, something seen most clearly with the failure of economics to predict, understand, or respond to the most recent economic crisis. This is part of a broader intellectual 'crisis of the modern disciplines' (Ibid.).

There is a long history of universities in the UK and a risk in over emphasising a romanticised notion what they involve. The existence of universities under capitalism has involved attempts to subsume research and teaching under the imperatives of capital. At first this involved elite training, but now universities play an increasingly larger role. In the current global higher education environment, UK universities remain public sector organisations and charities, but increasingly compete or collaborate with the private sector. The shift towards a knowledge based economy has involved pressure to 'reorient university teaching and research from alleged ivory-towered intellectual isolation towards closer and more continuous contact with the economy', however the 'university-corporate ties' in the USA go back until the eighteenth century (Jessop 2017, 855). For example, Cooke (1910) at the turn of the twentieth century, sought to apply Taylors scientific management techniques to the university. As Szadkowski (2016a) argues, control over and improving the effectiveness of academic labor are two long-term objectives in academia. What began with Cooke's research, was part of a larger trend to move academic institutions out of the crisis caused by both their overall financial decline and their lack of credibility where the general public was concerned (lbid.).

The application of Taylorist methods faces problems in terms of the measurability of academic work. The ability to take accurate measurements is a key part of Taylorism, often associated with the white-coated technicians standing over workers with stopwatches. As Beer $(2016,45)$ argues, 'measurement has the dual role of both capturing and setting standards, it records and produces.' The indeterminacy of labour power has been the key challenge of management since the first time a worker sold their time to a capitalist. The problem stems from buying labour-power from workers, but on trying to extract the maximum value from these purchases, discovering that it remains embodied in actual workers for whom working that hard is not in their interest. 
Often this is discussed in terms of motivation, but the 'inevitability of soldiering' - that workers are always trying to find a way to slow down - was a primary concern for Taylor (1967). The history of management has involved further attempts to solve this problem, but the first step is one of knowledge: needing to measure to be able to compare and attempt to speed up work. The same is true in universities: how can the use of academic labour be maximised without understanding what that labour is actually doing?

The use of digital technologies has greatly eased the possibilities of collecting, collating, and comparing statistics and metrics. In universities, a key rating has been citations - how many times articles have referenced a piece of research. As Pasquinelli (2009) has showed, experiments with methods to count citations provided the basis for Google's PageRank algorithm. It is therefore not enough to simply produce an academic output - for example, a journal article - but that output itself has to be measured along a variety of metrics: the quality of the journal in which it was published, the number of times it has been cited (in where the citing paper was published), and so on. This produces individual rankings for academics but also league tables between universities on a global level. As Szadkowski (2016a) points out, rankings by Thomson Reuters databases 'create a template for the measurement of the value of social relations in global academia, at the same time, they are used as a strict point of reference during national and institutional processes of evaluation of higher education systems, institutions and individual academics.' The measurement of academic output is generating vast amounts of metadata, something which allows for the 'measure of the value of social relations and a mechanism of social control' (Pasquinelli 2015, 63).

The use of these kinds of publication metrics have created 'publish or perish' pressures, leaving 'an indelible mark on contemporary academic life' (Fatsis 2016). This has been furthered by the 'interconnection between the academic journal publishing market and the global rankings' (Szadkowksi 2016a). The control over this aspect of measuring academic labour, along with enclosing much publicly funded research behind paywalls accessible only with extortionate fees, has proven a successful model for academic publishing. For example, Beverungen et al. $(2012,931)$ found that academic publishers could achieve as high as $40 \%$ margins. This is achieved by drawing on unpaid academic labour, exploiting the writing, editing, reviewing, and other activities without directly paying these vital parts, other than allowing access to metric rankings. For Szadkowski (2016a), this enclosure of academic research is part of a broader attempt by capital to first 'measure' and then 'appropriate the common.'

\section{The UK Context}

The contemporary landscape of universities in the UK has gone through a series of seismic shifts, the long-term impact of which is far from clear at this present moment. In this context, it is important to remember the primary concerns of universities: teaching, learning, and research. As Andrew McGettigan (2013) has highlighted, there is a long history of managerial audit culture in universities. This intensified with the introduction of the RAE (Research Assessment Exercise) and later the REF (Research Excellence Framework) that measures and compares academic research outputs across the UK. This is now going to be followed up with a teaching version: the TEF (Teaching Excellence Framework). This proliferation of numerical measurements, key performance indicators, and exit surveys has shifted the emphasis in universities towards quantitative outputs. This has been greatly facilitated by the proliferation of digital technologies, creating more opportunities for the generation, capture, and analysis of data. Across different disciplines there are increasing pressures to instrumentalise 
teaching and learning to cater to more employment focused elements as opposed to analysis and critique.

The risk of relying on statistics analysis is twofold, it fragments perspectives on university education, but there is also a question of whether statistics are actually measuring what they are intended to. At this point it is worth briefly considering the NSS (National Student Survey), the exit survey for final year undergraduate students used in the UK. Lee Harvey (2003) - the former director of research and evaluation of the Higher Education Academy - argued that when the NSS was being considered, 'the proposed national satisfaction poll would be a costly and pointless exercise [...] an unacceptable intrusion into university life that will damage existing improvement processes based on internal explorations of student satisfaction.' After the NSS had become a dominant indicator in the sector, Harvey (2008) again responded that the NSS was 'rapidly descending into a farce.' London Metropolitan University and Kingston University became embroiled in scandals of institutional manipulation and it is likely that many more have attempted subtler ways to influence their students. This is not an argument against consulting students about their opinions on education - far from it rather the effects of doing it in this way. Furedi and Attwood (2012) point out that the NSS 'possesses a corrosive immediacy that encourages the subordination of education and scholarship to the arbitrary imperative of student satisfaction.' Indeed, Bailey $(2013,143)$ has confirmed that 'the student experience' has become a 'leitmotif in pedagogical research.'

The problem with satisfaction is that it emphasises the consumption of education. Students are positioned as relatively passively consumers of an education that is packaged and delivered by academics. The comparison between institutions has a homogenising effect; experimentation is a risk and it is much safer to only make smaller modifications. This closes down potential alternative ways of organising teaching and learning, and in the process is narrowing the horizons of higher education. As Collini (2012, 17) has argued, universities are now struck by an 'obsession with global "league table" of universities' driven by 'subjective and inadequate opinion surveys' which 'provide little information that is both reliable and useful.' Furthermore, Collini $(2012,185)$ suggests that the notion of 'student satisfaction' is itself highly problematic, reducing the experience of teaching and learning to "a set of "preferences" as reported on a tick-box questionnaire' aligned with the idea of satisfaction. This is a strange notion in education, as Collini (lbid.) points out, 'a "satisfied" student is nigh-on ineducable.' This reduces teaching to an exchange, a purchase, as if you can buy something as indeterminable as a learning experience.

The REF and the TEF are the clearest examples of metrics that have been introduced in the UK and play an important role in measuring the outputs of academics. As Burrows (2012) has argued, the metrics have combined with markets and affects in universities in the UK to form a kind of 'quantified control.' This includes the use of multiple metrics, citations of papers, regular assessment from outside the university and by students, modelling workloads, distribution of research funding, costing models, league tables, and so on to introduce market pressures into universities in the UK.

The success in measuring and comparing academics and universities in the UK has provided the basis for planning future changes. 'Success' in this context is considered as the ability to boil down the complexity of teaching and research to single digit measurements, allowing easy comparisons to be made without prior knowledge of the institutions or disciplines (Collini 2012, 37). The real success of these metrics has not been to provide meaningful comparisons between diverse subject areas or institutions, but to create competition which, as McGettigan $(2013,12)$ argues, 'will lead to upheaval: 
transforming institutions from within but also from without.' In other words, through these policies, 'the government is taking a huge gamble with England's universities, introducing uncertainty into a stable and productive system, though one not without faults' (McGettigan 2013, 22). For academic working in universities it has also introduced pressures that allow the interests of capital and management to become deeply written into their activities.

\section{The Academic Labour Process}

After looking at the broader context of what is happening in universities in the UK, the next part of this paper focuses down on the labour process of academics and its transformation through the application of digital technology. As Szadkowski $(2016 b, 9)$ points out, a critical project in a university needs to begin 'primarily' with 'the categories of academic living labour/knowledge, as both the source of social wealth, as well as the source of capital'. Furthermore, Winn $(2014,2)$ notes that on the subject of academic work, 'there is relatively little critical engagement with labour itself as the object of critique.' By returning the analysis to the labour process, and seeking to understand how this is changed by the dynamics discussed above, along with the introduction of new technology, this section seeks to discuss academic work in a new light. For Marx $(1990,284)$, the labour process involved three simple elements: first, the 'purposeful activity, that is work itself'; second, the 'objects on which that work is performed'; and third, the 'instruments of that work.'

The 'purposeful activity' of academic work is broadly divided into three parts: research, teaching, and administration. Due in part to digitalisation, each of these activities have been 'accelerated' with increasing time pressure (Vostal 2016), increasing the volume and speed of work that academics are expected to complete. The creative dimensions of academic work (the need to produce new and meaningful ideas, or to provide up to date and relevant teaching), along with the classic problem of the indeterminacy of labour, make straightforward forms of managerial control difficult. Instead of the dictatorial and electronically enabled forms of control and surveillance found, for example, in call centres (Woodcock 2017), there is the pressure of the abstracted metrics discussed previously. Like with other forms of digital and creative labour, there is the need for capital (or its managerial representatives) to 'balance' the 'insatiable need for a stream of innovative ideas with the equally strong imperative to gain control over intellectual property' and workers (Huws 2010, 504). Thus, the work itself is often removed from direct forms of managerial control, with academic workers left to motivate themselves to reach targets on research or teaching. The application of digital technologies 'have fundamentally transformed knowledge production', applying 'not only to how we create, disseminate, and consume knowledge, but also who, in this case, counts as "we"' in universities (Bacevic 2017). In this way, digital technologies have become increasingly bound up with the actual processes of knowledge construction itself, not only changing how this happens but also opening up the processes to a broader range of actors

The 'objects on which that work is performed' is complicated by the differences in the purposeful activities of academic work. The first 'object' is that of published knowledge, the creation of journal articles and books, subjected as they are to detailed metrics and comparison, and enclosed by publishers. The publication of this kind of research has become a key concern for academics in order to achieve particular rankings, although the critique of academia has usually aimed for a broader audience than only other academics in their discipline - or just the editor and peer-reviewers of a journal. As Bacevic (2017) points out, from the 'petitions and pamphlets in the Dreyfus 
affair' to more contemporary discussion on social media, 'there is no critique without an audience, and digital technologies are essential in how we imagine them.' The public sphere - mediated in various ways by different technologies - is a terrain of debate that academics can intervene in, successfully or otherwise. Social media, in this vein, becomes one of the 'main vehicles for dissemination' of critique (Bacevic 2017). For example, Hall (2016) poses the question (in the context of rankings faced by many precarious workers) about whether 'in the future, are academics going to have to manage their reputations too?' then follows it up with: 'are we going to have to put a lot of work into performing sociality with our colleagues, students, peers, and friends on Facebook, Twitter, and Academia.edu to ensure that we maintain a good reputation score?' However, the need to actively maintain and effectively utilise social media (Carrigan 2016) is already a major concern for precarious academics.

In the context of teaching, the relationship between students and teachers is increasingly being mediated by digital technologies. The most obvious example of this is the ubiquity of email communication. Teachers in university are expected to be constantly available by email, with the smartphone notification becoming a near-constant reminder of the pressures of academic work. Teaching materials are made available on virtual learning environments, with the expectation of additional resources. While this is a good way to increase the accessibility of materials, it is being furthered with electronic lecture capture. The use of technology to extend the learning experience, particularly for those with access issues or different learning requirements, is potentially positive, however the capture of lectures creates other tensions. Anecdotally, lecture attendance falls when the lecture is available for replay later, missing out on the importance of contact between lecturer and students - something that is already limited in the contemporary university. Additionally, the record of 'e-learning and of distance education technologies [...] have cost cutting (above those associated with the labor force) as their primary objective', seen with the attempts by the University of Phoenix which is premised on the complete technological substitution of the class experience (Roggero 2011, 115). Thus, the suggestion of lecture capture also comes with the risk of academic labour being expelled from the teaching process. These elements form part of the broader tendency that is 'rapidly drawing the halls of academe into the age of automation' as outlined previously by David Noble (1998).

The third key change to the labour process relates to the 'instruments of that work.' The historical image of the academic working in dusty offices or libraries is increasingly giving way to that of a person typing away on a laptop, whether at home, an office (possibly shared), or a coffee shop with wifi. These shifts are also related to teaching. For example, when Bourdieu $(2008,175)$ discussed the 'whole series of techniques' that are 'tacitly required by all teaching', he listed the: use of dictionaries and abbreviations, rhetoric of communication, establishment of files, creation of an index, use of records and data banks, preparation of a manuscript, documentary research, use of computerised instruments, interpretation of tables and graphs, etc.' It would be easy to imagine a whole range of new digitally enabled techniques in the modern university: online searching, navigating proprietary journal databases to find access to articles, effective use of social media, maintaining online resources, and so on.

One of the interesting dynamics that this introduces, as opposed to the analogue resources of the physical library, is a physical decoupling of the instruments of academic work from a geography of the university. In this sense, the university becomes more like a platform - allowing access to institutional subscriptions, email accounts, and other online resources, that do not require a worker to physically be present within 
the university itself. Hall (2016) imagines a near dystopian future that can take advantage of this transformation of the university, in which academic workers 'have little choice but to sell their cheap and easy-to-access courses to whoever is prepared to pay for them in the "alternative" sharing economy education market created by platform capitalism.' The relative freedom of being able to use digital tools to engage with teaching, research, and administration to engage with the university from wherever workers choose also creates the possibility of greater precarisation and outsourcing via a platform mode of organisation. The changes that the digitalisation of the academic labour process creates are summarised in the table below.

\begin{tabular}{|l|l|l|}
\hline \multicolumn{1}{|c|}{ The Labour Process } & \multicolumn{1}{|c|}{ Academic work } & Impact of Digitalisation \\
\hline $\begin{array}{l}\text { The 'purposeful activity, } \\
\text { that is work itself' }\end{array}$ & $\begin{array}{l}\text { Research, teaching, } \\
\text { Administration }\end{array}$ & $\begin{array}{l}\text { Acceleration of activities, } \\
\text { linked to managerial strat- } \\
\text { egies of control }\end{array}$ \\
\hline $\begin{array}{l}\text { The 'objects on which that } \\
\text { work is performed' }\end{array}$ & $\begin{array}{l}\text { Research outputs (journal } \\
\text { articles, books, publicity), } \\
\text { teaching materials }\end{array}$ & $\begin{array}{l}\text { Online media outputs and } \\
\text { new metrics for research } \\
\text { success. Email, online } \\
\text { materials and lecture cap- } \\
\text { ture for teaching. New } \\
\text { methods of control. }\end{array}$ \\
\hline $\begin{array}{l}\text { The 'instruments of that } \\
\text { work' }\end{array}$ & $\begin{array}{l}\text { Tools for researching, } \\
\text { writing, and teaching }\end{array}$ & $\begin{array}{l}\text { New skill requirements } \\
\text { and the university becom- } \\
\text { ing more like a platform. }\end{array}$ \\
\hline
\end{tabular}

Table 1: The digitalisation of the academic labour process

These three component points are key to the analysis here. However, across each of these dimensions is another factor that is greatly transforming the labour process of academics: precarity. As Montoya and Pérez (2016) note, 'in conversation, scholars cannot help but constantly raise the subject of their increasingly precarious working conditions and the anxieties that derive from them.' Precarity has become a prominent feature of working in a UK university - or universities if multiple part time contracts are entered into simultaneously. For example, Weber $(1946,129)$ wrote about how an academic career in Germany was 'generally based on plutocratic premises' and that 'it is extremely risky for a young scholar without private means to expose himself to the conditions of an academic career. He must be able to survive at least for a number of years without knowing whether he has any prospects of obtaining a position that will enable him to support himself.' The contemporary precarity in academia is 'deepened and exacerbated by other processes attuned with neoliberal logics' (Montoya and Pérez 2016) that have started with the introduction of detailed metrics, greatly improved and accelerated in a digital context. 


\section{Towards an Alternative}

The previous sections have sketched out the role of the university and knowledge under capitalism, examined the particular UK context, and analysed the changes of the academic labour process through digitalisation. However, what is missing so far is the resistance of workers in the university to these changes, both for academics and the other forms of work upon which the university relies (Woodcock 2014a). However, since the disastrous pensions dispute, the University and College Union (UCU) has been particularly absent. There have been a number of campaigns by casualised academic workers, for example at Goldsmiths ${ }^{1}$ and SOAS ${ }^{2}$, but nothing has been organised in a sustained way on a national level. There are lessons that can be learnt from the Operaismo (or Italian Workerism) to guide analysis of the contemporary problems of academic work, resistance, and what kinds of organisation could be effective. Although this article has focused on tracing the changes from-above (as it were) that are transforming universities, this only provides a partial account of how knowledge is being produced. The core of this kind of analysis begins, as Tronti $(1971,89)$ argued, by 'invert[ing] the problem', to 'change direction, and start from the beginning - and the beginning is working-class struggle.' The problem with this approach in the university is that there is not a wide range of open struggles from which this analysis can begin.

An important contribution of Operaismo is the idea of class composition, which is particularly useful here. This considers the analysis of work along two dimensions. The first is the technical composition; including: the labour process, the application of technology, management strategies, and the conditions of the reproduction of labour power. The second, and related although not determined by the former, is the political composition: the practices, traditions, and forms of struggle, something that is itself continually in a process of re-composition. The stringent pressures of rankings and metrics combine to create conditions within the technical composition that lead to what Roggero $(2011,23)$ has called 'blockages' within the struggles of precarious academic workers. As he has argued 'to use operaismo's classic terms, the political composition of the class is crushed within the sociological mold of its technical composition' (lbid.).

The result of the 'blockages' is that sustained struggle within the university has become limited, giving the impression that not much is currently happening on the terrain of workplace struggle. One important limitation is that trade union demand remain at the level of wages or pensions, not taking on question of control. By failing to contest control over the organisation of work by management, workers themselves are left in a difficult structural position. The drastic shift in the frontier of control in the workplace means that it no longer appears as something that can even be contested, leaving significant power in the hands of management. This represents the further 'subsumption' of capital over labour within the university (Szadkowski 2016b, 10). The push for intensifying work through metrics and digital technologies, particularly through what Dardot and Laval $(2013,261)$ have termed 'entrepreneurial self-government' limits the scope further. The precariousness of academic work also contains an element of 'autoprecarization', and Montoya and Pérez (2016) warn that academics need to consider 'our contribution to dragging others into precarity (as a condition of vulnerability not restricted to labour) within and beyond the walls of universities'.

\footnotetext{
${ }^{1}$ See: http://www.newleftproject.org/index.php/site/article comments/the postgraduate workers association

2 See: http://fractionalsforfairplay.webs.com
} 
In previous years, particularly during the wave of student protests in 2010, questions around the role of the university and its future were vigorously debated. Following the decline of that movement, along with the failure of a number of trade union campaigns, the horizons of struggle in the university have significantly narrowed. However, the university remains an important site for research, particularly as it can combine both the objects and subjects of research. The combination of education and technology 'offers mechanisms through which one might challenge, resist and push-back against the marketization of public education, indentured study and the hidden curriculum that asserts the primacy of value-for-money, impact metrics, productivity and efficiency' (Hall 2015, 121).

An important way forward here is the notion over 'conricera' that Roggero (2011, 136) discusses as a key innovation of Operaismo. This idea of co-research builds on the traditions of workers' inquiry, starting with Marx's (1880) call for a survey of working conditions. This inspired a critical Marxist approach that sought to combine the construction of knowledge about workplaces with new experiments in organising (Woodcock, 2014b). It involves the blurring of the traditional barriers between researcher and subject, seeking to go beyond the organisational and disciplinary (in both senses of the term) bounds of the university. Roggero $(2011,141)$ argues that when:

Knowledge becomes the central resource and means of production, the intellectual function is completely absorbed within the new class composition, and in cognitive labor are traced the coordinates and cooperation and exploitation, conricerca can become a directly constituent practice. Reconfiguring its location from spatial continuity towards the preeminence of the temporal, conricerca is potentially an instrument for the exercise of the autonomy of living labor and the method for the construction of the institutions of the common.

This is an important reminder for contemporary academic work. The university is a site in which research tools are developed, research is undertaken, and new analysis proposed. However, too often these are not applied to the academic work within the boundaries of the university. Co-research provides an important way to refresh the analysis of academic work, not only to propose new ideas, but also to experiment with new forms of organisation that can go beyond the blockages of the neoliberal university. Rather than watching the new digital tools being used to further the precariousness and alienation of academic work, they can be adapted and modified to fit a project for a very different kind of university.

In practice, this means re-thinking what kinds of research should be undertaken and how it can be carried out. If the university is becoming increasingly digitalised and precarious, there are many other examples of work beyond the campus that are being transformed in this way too. Through initiating collaborative research projects (forms of co-research) with other groups of workers, the existing methods and digital tools can be repurposed for projects that not only seek to generate knowledge about these conditions, but also aim to change them. In particular, the so-called gig-economy has become a testing ground for both new managerial techniques and forms of workplace struggle. By engaging in critical projects in these areas research can play a role in supporting other workers, but within this reflexive process the university too can begin to be changed. 


\section{References}

Bacevic, Jana. 2017. @Grand Hotel Abyss: Digital University and the Future of Critique. Discover Society, January 3. Accessed 22 January 2018. http://discoversociety.org/2017/01/03/grand-hotel-abyss-digital-university-and-the-future-of-critique

Bailey, Richard. 2013. Exploring the Engagement of Lecturers with Learning and Teaching Agendas Through a Focus on Their Beliefs About, and Experience with, Student Support. Studies in Higher Education 38 (1): 143-155.

Bain, Peter, Aileen Watson, Gareth Mulvey, Phil Taylor and Gregor Gall. 2002. Taylorism, Targets and the Pursuit of Quantity and Quality by Call Centre Management. New Technology, Work and Employment 17 (3): 170-185.

Beer, David. 2016. Metrics Power. Basingstoke: Palgrave MacMillan.

Beverungen, Armin, Steffan Böhm and Chris Land. 2012. Poverty of Journal Publishing. Organization 19 (6): 929-938.

Bourdieu, Pierre. 2008. Political Interventions: Social Science and Political Action. London: Verso.

Braverman, Harry. 1999. Labor and Monopoly Capitalism: The Degradation of Work in the Twentieth Century. London: Monthly Review.

Burrows, Roger. 2012. Living with the H-Index? Metric Assemblages in the Contemporary Academy. The Sociological Review 60 (2): 355-372.

Carrigan, Mark 2016. Social Media for Academics. London: Sage.

Castells, Manuel. 2000. The Rise of the Network Society. Oxford: Blackwell.

Collini, Stefan. 2012. What Are Universities For? London: Penguin Books.

Cooke, Morris Llewellyn. 1910. Academic and Industrial Efficiency. A Report to the Carnegie Foundation for the Advancement of Teaching. New York.

Dardot, Pierre and Christian Laval. 2013. The New Way of the World: On Neo-Liberal Society. London: Verso.

Dyer-Witheford, Nick. 2010. Digital Labour, Species-Becoming and the Global Worker. ephemera: theory \& politics in organization 10 (3/4): 484-503.

Fatsis, Lambros. 2016. The New Rules of Sociological Labour. The Sociological Review Blog, September 19. Accessed 22 January 2018. https://www.thesociologicalreview.com/blog/the-new-rules-of-sociological-labour.html

Fernie, Sue and David Metcalf. 1997. (Not) Hanging on the Telephone: Payment Systems in the New Sweatshops. London: Centre for Economic Performance at the London School of Economics and Political Science.

Frey, Carl Benedikt and Michael A. Osborne. 2013. The Future of Employment: How Susceptible are Jobs to Computerisation. Accessed 27 July, 2017. http://www.oxfordmartin.ox.ac.uk/downloads/academic/The Future of Employment.pdf

Furedi, Frank and Rebecca Attwood. 2012. Satisfaction and Its Discontents. Times Higher Education, March 8. Accessed 22 January 2018. http://www.timeshighereducation.co.uk/419238.article

Hall, Gary. 2016. The Uberfication of the University. Minneapolis: University of Minnesota Press.

Hall, Richard. 2015. The Implications of Autonomist Marxism for Research and Practice in Education and Technology. Learning, Media and Technology 40 (1): 106-122.

Handy, Charles. 1984. The Future of Work: A Guide to a Changing Society. Oxford: Blackwell.

Harvey, Lee. 2008. Jumping Through Hoops on a White Elephant: A Survey Signifying Nothing. Times Higher Education, June 12. Accessed 22 January 2018. http://www.timeshighereducation.co.uk/402335.article

Harvey, Lee. 2003. Scrap That Student Survey Now. Times Higher Education, December 12. Accessed 22 January 2018. http://www.timeshighereducation.co.uk/185492.article 
Huws, Ursula. 2010. Expression and eExpropriation: The Dialectics of Autonomy and Control in Creative Labour. ephemera: theory \& politics in organization 10 (3/4): 504-521.

Huws, Ursula. 2001. The Making of a Cybertariat? Virtual Work in a Real World. Socialist Register 37: 1-23.

Jessop, Bob. 2017. Varieties of Academic Capitalism and Entrepreneurial Universities. Higher Education. 73: 853-870.

Marx, Karl. 1880. A Workers' Inquiry. Accessed July 27, 2017. https://www.marxists.org/archive/marx/works/1880/04/20.htm

Marx, Karl. 1976/1857. Grundrisse. London: Penguin.

Marx, Karl. 1990/1867. Capital, Volume 1: A Critique of Political Economy. London: Penguin. Marx, Karl. 1991/1894. Capital, Volume 3: A Critique of Political Economy. London: Penguin.

McGettigan, Andrew. 2013. The Great University Gamble: Money, Markets and the Future of Higher Education. London: Pluto.

Montoya, Ainhoa and Marta Pérez. 2016. Unravelling Academic Precarity \#UniversityCrisis. Allegra Lab, December 8. Accessed 22 January 2018. http://allegralaboratory. net/unravelling-academic-precarity-universitycrisis

Morgan, Marcus and Patrick Baert. 2015. Conflict in the Academy: A Study in the Sociology of Intellectuals. London: Palgrave Macmillan.

Noble, David. 1998. Digital Diploma Mills: The Automation of Higher Education. First Monday 3 (1). Accessed July 27, 2017. http://journals.uic.edu/ojs/index.php/fm/article/view/569/490

Nonaka, Ikujiro. 1998. The Knowledge-Creating Company. Harvard Business Review on Knowledge Management. Boston: Harvard Business School Press.

Pasquinelli, Matteo. 2015. Italian Operaismo and the Information Machine. Theory, Culture \& Society 32 (3): 49-68.

Pasquinelli, Matteo. 2011. Machinic Capitalism and Network Surplus Value: Notes on the Political Economy of the Turing Machine. Accessed July 27, 2017. http://ge.tt/40VrLRa/v/0

Pasquinelli, Matteo. 2009. Google's PageRank Algorithm: A Diagram of Cognitive Capitalism and the Rentier of the Common Intellect. In Deep Search: The Politics of Search Beyond Google, edited by Konrad Becker and Felix Stalder, 152-163. London: Transaction Publishers.

Roggero, Gigi. 2011. The Production of Living Knowledge: The Crisis of the University and the Transformation of Labor in Europe and North America. Philadelphia: Temple University Press.

Szadkowski, Krystian. 2016a. Socially Necessary Impact/Time: Notes on the Acceleration of Academic Labor, Metrics and the Transnational Association of Capitals. Teorie vědy (Theory of Science) 38 (1): 53-85.

Szadkowski, Krystian. 2016b. Towards an Orthodox Marxian Reading of Subsumption(s) of Academic Labour under Capital. Workplace 28: 9-29.

Taylor, Frederick Winslow. 1967. The Principles of Scientific Management. New York: Norton.

Tronti, Mario. 1971. Operai e Capitale. Turin: Einaudi.

Tronti, Mario. 1965. The Strategy of the Refusal, Operai e Capitale ("Workers and Capital"). Accessed July 27, 2017. https://libcom.org/book/export/html/439

Virno, Paolo. 2001. General Intellect. Translated by Arianna Bove. Accessed July 27, 2017. http://www.generation-online.org/p/fpvirno10.htm

Vostal, Filip. 2016. Accelerating Academia: The Changing Structure of Academic Time. Basingstoke: Palgrave Macmillan.

Weber, Max. 1946. Science as Vocation. In Max Weber: Essays in Sociology, edited and translated by Hans H. Gerth and C. Wright Mills. New York: Oxford University Press: 129156.

Winn, Joss. 2014. Writing About Academic Labour. Workplace: A Journal for Academic Labour 25: 1-15. 
Woodcock, Jamie. 2017. Working the Phones: Control and Resistance in Call Centres. London: Pluto.

Woodcock, Jamie. 2014a. Precarious Work in London: New Forms of Organisation and the City. City: analysis of urban trends, culture, theory, policy, action 18 (6): 776-788.

Woodcock, Jamie. 2014b. The Workers' Inquiry from Trotskyism to Operaismo: A Political Methodology for Investigating the Workplace. ephemera: theory \& politics in organization 14 (3): 493-513.

Wright, Steve. 2016. Working with Information: Some Initial Enquiries. In Class and Librarianship: Essays at the Intersection of Information, Labor and Capital, edited by Erik Estep and Nathaniel Enright, 73-102. Sacramento: Library Juice Press.

\section{About the Author}

\section{Jamie Woodcock}

Jamie Woodcock is a fellow at the LSE and author of Working The Phones. His current research focuses on digital labour, the sociology of work, the gig economy, resistance, and videogames. He has previously worked as a postdoc on a research project about videogames, as well as another on the crowdsourcing of citizen science. Jamie completed his PhD in sociology at Goldsmiths, University of London and has held positions at Goldsmiths, University of Leeds, University of Manchester, Queen Mary, NYU London, and Cass Business School. 